Brit. F. vener. Dis. (1968), 44, 140.

\title{
A STUDY OF THE RELATIONSHIPS BETWEEN THE SENSITIVITIES OF Neisseria gonorrhoeae TO SODIUM PENICILLIN G, FOUR SEMI-SYNTHETIC PENICILLINS, SPIRAMYCIN, AND FUSIDIC ACID* $\dagger$
}

BY

\author{
ALICE REYN AND MICHAEL WEIS BENTZON \\ From the WHO International Reference Centre for Gonococci, and the Neisseria Department and Department of \\ Biostatistics, Statens Seruminstitut, Copenhagen, Denmark
}

During recent years the sensitivity of Neisseria gonorrhoeae to a series of antibiotics has been determined in the Neisseria Department of the Statens Seruminstitut, Copenhagen. Initially, the purpose was to discover the range of sensitivity to various antibiotics of possible use in the treatment of gonorrhoea. Having observed certain characteristic features in the correlation between the sensitivities to these antibiotics and sodium penicillin $G$, the examination was extended to comprise semisynthetic penicillins, and more strains were studied.

The relationships between sodium penicillin $G$, tetracycline, and streptomycin had been investigated previously; with strains isolated in 1944, the sensitivities to penicillin and streptomycin were negatively correlated but with strains isolated after 1957 a positive correlation was observed. The penicillin and tetracycline values have always been found to be positively correlated, but whereas the streptomycin and tetracycline values showed a negative correlation in strains isolated in 1944, a positive correlation was invariably observed in strains isolated after 1957 (Reyn, Korner, and Bentzon, 1958; Reyn, 1961; Reyn and Bentzon, 1961; Schmidt and Larsen, 1962; Reyn, 1963; Schmidt, Niordson, Reyn, and Bentzon, 1965; Reyn, 1966; Reyn, unpublished data, 1967).

\section{Strains}

\section{Material and Methods}

(a) Altogether 493 fresh strains of $N$. gonorrhoeae were tested to sodium penicillin $G$, tetracycline, and streptomycin, using the plate-dilution method described by Reyn and co-workers. The results were given in $\mu \mathrm{g} . / \mathrm{ml}$. of 50 per cent. inhibitory concentrations

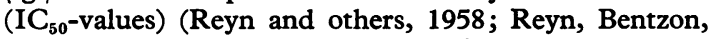
and Ericsson, 1963). Strains with $\mathrm{IC}_{50}$-values $\geqq 0.045$ $\mu \mathrm{g}$. sodium penicillin $\mathrm{G}$ per $\mathrm{ml}$. were considered "less sensitive". The majority of the strains were picked out at random from the specimens received with a request for sensitivity determination to these drugs; in November, 1965, fifteen strains from the routine samples

* Received for publication August, 1967.

+ This study was supported by grants from the World Health Organization. representing a suitably wide range of sensitivity to penicillin were used as a supplement. 62 strains were isolated in $1961,101(96+5)$ strains in 1962,173 strains in 1963, 92 strains in 1964, fifteen strains in 1965, and fifty strains in January, 1966.

The experimental errors were examined in series of duplicate titrations. On the average, the standard deviation of $\log \mathrm{IC}_{50}$ was $0 \cdot 135$, the corresponding 95 per cent. limits of error being from 54 to 186 per cent. In addition to the routine testings to sodium penicillin G, tetracycline, and streptomycin, some of the strains were re-examined to sodium penicillin $G$ and simultaneously to one or more of the other antibiotics, using two-fold dilution steps for all the antibiotics.

(b) Five of the gonococcal strains isolated in 1962, being originally less sensitive to penicillin and tetracycline and also resistant to streptomycin, were subcultured on plates with increasing concentrations of sodium penicillin $G$. On the average, these strains had $\mathrm{IC}_{50}$-values of about $1 \mu \mathrm{g}$. sodium penicillin $\mathrm{G}$ per $\mathrm{ml}$. Two extra series of strains with a further decreased sensitivity to sodium penicillin $G$ were obtained. One series was lyophilized after 2 months' subculturing and the other series was transferred for about 3 months before lyophilization. The mean sensitivity to sodium penicillin $G$ of the former strains was about three times less than that originally found, and the mean decrease of the latter was about seven times that originally observed. The sensitivities of the original strains and of those selected on media with increasing amounts of sodium penicillin $G$ were examined against all the antibiotics included in the present investigation.

\section{Antibiotics}

The antibiotics employed are listed in Table I (opposite).

\section{Results}

\section{Range and Distribution}

Figs 1 (opposite) and 2 (overleaf) show the distributions of the $\mathrm{IC}_{50}$-values obtained with the different antibiotics.

Methicillin The range and distribution of the IC $_{50}$-values of strains isolated in March, 1961 (61 strains) and of those isolated in September, 1963 (73 strains) were only slightly different; in September, 1963 , the range of $\mathrm{IC}_{50}$-values was a little wider, and 
TABLE I

DATE OF ISOLATION OF STRAINS TESTED AND ANTIBIOTICS USED

\begin{tabular}{|c|c|c|}
\hline Antibiotics & Number of & Isolated in: \\
\hline $\begin{array}{l}\text { Benzylpenicillinnatrium NFN } \\
\text { (Sodium penicillin G; Penicillin }^{\circledR}, \text { LEO) } \\
(a)\end{array}$ & 493 & March, 1961, and Jan., 1966 \\
\hline $\begin{array}{l}\text { Dihydrostreptomycinum NFN } \\
{\text { (Streptomycin; Dihydrostreptomycinum }{ }^{\otimes}, \text { LEO) }}^{(b)}\end{array}$ & 493 & Sep., 1963, and Dec., 1963 \\
\hline $\begin{array}{l}\text { Tetracyclinum NFN } \\
{\text { (Tetracycline; Tetracyclin, }{ }^{\circledR} \text { Lepetit) }}^{(c)}\end{array}$ & 493 & Sep., 1963, and Dec., 1963 \\
\hline $\begin{array}{l}\text { Meticillin NFN } \\
\text { (Methicillin; Lucopenin }{ }^{\circledast}, \text { Lundbeck and Co.) }\end{array}$ & $149^{(d)}$ & March, 1961, and Sep., 1963 \\
\hline $\begin{array}{l}\text { Oxacillin US } \\
\text { (Pro-staphlin }{ }^{\circledR}, \text { Lundbeck and Co.) }\end{array}$ & $88^{(d)}$ & Sep., 1963, and Dec., 1963 \\
\hline $\begin{array}{l}\text { Ampicillinum INN } \\
\text { (Ampicillin; Doktacillin }{ }^{\circledR}, \text { Astra; Pentrexyl }{ }^{\circledR}, \text { Lundbeck and Co.) }\end{array}$ & $180^{(d)}$ & Sep., 1963, and March, 1964 \\
\hline 3-amino-adamantyl-1-penicillin ${ }^{(e)}$ & $65^{(d)}$ & Jan., 1966 \\
\hline $\begin{array}{l}\text { Spiramycinum NFN } \\
\left.\text { (Spiramycin; Rovamycin }{ }^{\circledR}, M \text { and } B\right)\end{array}$ & 173 & Sep., 1963, and Dec., 1963 \\
\hline $\begin{array}{l}\text { Acidum fusidicum NFN } \\
\text { (Fusidic acid; Fucidin }{ }^{\circledR}, \text { LEO) }\end{array}$ & 96 & Aug., 1962 \\
\hline
\end{tabular}

(a) Strains with $\mathrm{IC}_{\mathrm{s0}}$-values $\geqq 0.045 \mu \mathrm{g}$. $/ \mathrm{ml}$. are considered less sensitive.

(b) Only one plate with $25 \mu \mathrm{g} . / \mathrm{ml}$. is used.

(c) Strains with $\mathrm{IC}_{50}$-values $\geqq 1 \cdot 13 \mu \mathrm{g} . / \mathrm{ml}$. are considered less sensitive.

(d) Fifteen selected strains included, all from November, 1965.

(e) This substance was supplied to the authors from LEO, Copenhagen, Denmark, at a stage at which it had not yet been decided whether it should be recommended for clinical use; during the experimental period it was decided not to recommend it.

the proportion of strains less sensitive to methicillin was slightly greater. Ignoring these minor deviations, the range and distribution of all 134 strains were considered together, and their $\mathrm{IC}_{50}$-values were found to range from 0.016 to $29 \mu \mathrm{g}$. $/ \mathrm{ml}$. They were distributed with two peaks, one at about $0.045 \mu \mathrm{g} . / \mathrm{ml}$. and the other between 3 and $12 \mu \mathrm{g} . / \mathrm{ml}$. The fifteen selected strains were within the range described.

Oxacillin The $\mathrm{IC}_{50}$-values of the 73 strains from September, 1963, ranged from 0.05 to 30 $\mu \mathrm{g} . / \mathrm{ml}$. The distribution showed two peaks, one at about $0.4 \mu \mathrm{g} . / \mathrm{ml}$. and the other at about $9 \mu \mathrm{g} . / \mathrm{ml}$. One of the $\mathrm{IC}_{50}$-values of the fifteen selected strains fell beyond the range described, viz. $50 \mu \mathrm{g} . / \mathrm{ml}$.

Ampicillin The $\mathrm{IC}_{50}$-values of the strains from September, 1963, and of those from March to June, 1964, differed neither in range nor in distribution; therefore they were taken together. The $\mathrm{IC}_{50}$-values of the 165 strains ranged from 0.006 (a single strain 0.002 ) to $0.50 \mu \mathrm{g} . / \mathrm{ml}$. The distribution was twopeaked with maxima at about 0.02 and $0.15 \mu \mathrm{g} . / \mathrm{ml}$. The $\mathrm{IC}_{50}$-values of the fifteen selected strains fell within the range described.

3-Amino-adamantyl-1-penicillin The $\mathrm{IC}_{50}$-values of the fifty strains isolated in January, 1966, ranged from 0.01 to $1 \mu \mathrm{g} . / \mathrm{ml}$.; they were distributed in two groups with maxima at about 0.04 and 0.5 $\mu \mathrm{g} . / \mathrm{ml}$. The $\mathrm{IC}_{50}$-values of the selected strains fell within the range described.
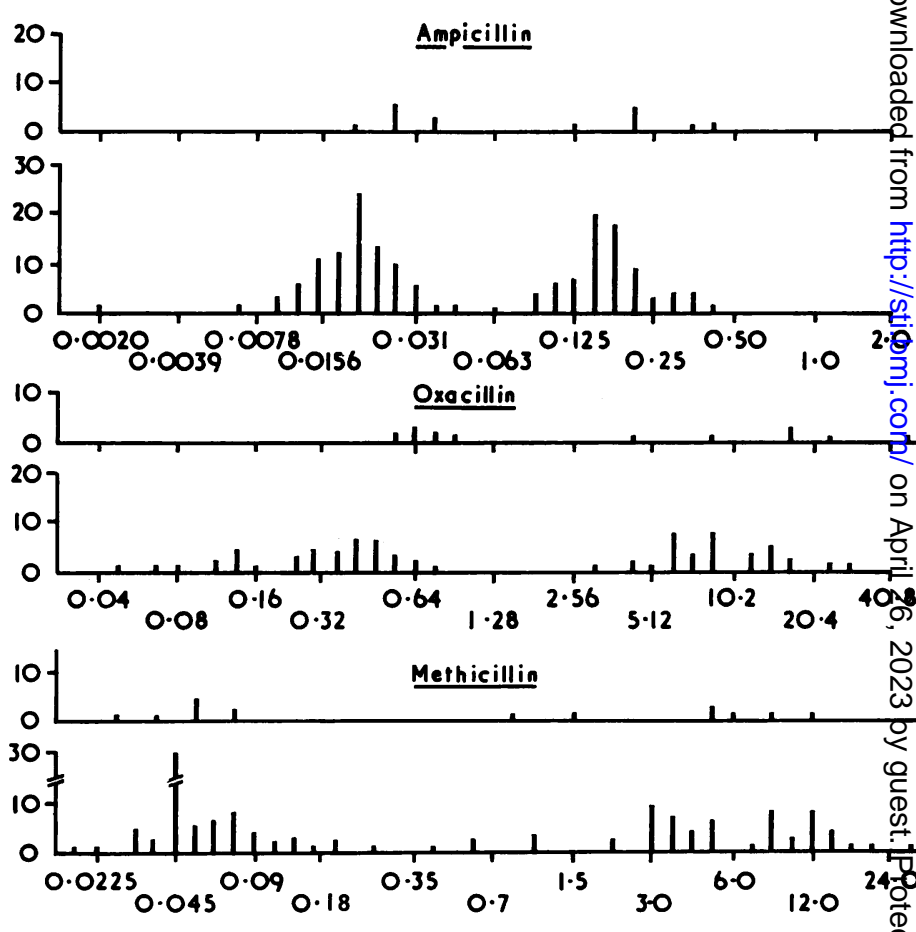

ICso $\mu \mathrm{g} . / \mathrm{ml}$.

FIG. 1.- $\mathrm{IC}_{50}$-values in $\mu \mathrm{g} . / \mathrm{ml}$. of ampicillin, oxacillin and methicillin. Range and distribution 
Fusidic Acid The $\mathrm{IC}_{50}$-values of the 96 strains isolated in August, 1962, ranged from 0.04 to 3 $\mu \mathrm{g} . / \mathrm{ml}$. with a peak between 0.4 and $1.6 \mu \mathrm{g} . / \mathrm{ml}$. The distribution was skew to the side of the relatively resistant strains.

Spiramycin The $\mathrm{IC}_{50}$-values of the 173 strains isolated in the last half of 1963 ranged from 0.05 to $1.6 \mu \mathrm{g} . / \mathrm{ml}$. with a peak at about $0.6 \mu \mathrm{g} . / \mathrm{ml}$. The distribution was normal.

\section{Comparison between Sodium Penicillin G and the Other Antibiotics in Individual Gonococcal Strains}

In Figs 3 to 8 the $\mathrm{IC}_{50}$-values obtained with $\frac{\mathrm{E}}{2}$ sodium penicillin $\mathrm{G}$ are plotted on the abscissae and the corresponding $\mathrm{IC}_{50}$-values of the various antibiotics are plotted on the ordinates. At present, in the routine, the $\mathrm{IC}_{50}$-values obtained with sodium penicillin $\mathrm{G}$ range from $\leqq 0.001$ to $1.4 \mu \mathrm{g} . / \mathrm{ml}$.; they are distributed with two maxima, one at about 0.005 and the other at about $0.3 \mu \mathrm{g}$. $/ \mathrm{ml}$. (1963-66; 8,814 strains sent in with a request for sensitivity determination (Reyn, 1966; Reyn, unpublished data, 1967)). The corresponding tetracycline values range from $\leqq 0.1$ to $4.5 \mu \mathrm{g}$. $/ \mathrm{ml}$., also with two maxima, one at about $0.3 \mu \mathrm{g} . / \mathrm{ml}$. and the other between 1.13 and $1.6 \mu \mathrm{g} . / \mathrm{ml}$. with very few values beyond 1.6 $\mu \mathrm{g} . / \mathrm{ml}$. In Figs 3 to 8 , the symbols for strains resistant to streptomycin (o) and those sensitive to this substance $(\bullet)$ are different. On the average, 21 per cent. of the strains sent in at present with a request for sensitivity determination are completely resistant to streptomycin. The sensitivity to streptomycin is tested on only one plate containing 25 $\mu \mathrm{g} . / \mathrm{ml}$., the general experience being that the IC $_{50}$-values of gonococcal strains are either $\leqq 12-16$ $\mu \mathrm{g} . / \mathrm{ml}$. or $\geqq 2000 \mu \mathrm{g} . / \mathrm{ml}$.

Comparison with Methicillin In Fig. 3 the IC $_{50}$-values obtained with methicillin in 149 strains are plotted on the ordinate. A straight line is drawn through $\mathrm{IC}_{50}$-values ten-fold higher on the ordinate than those on the abscissa; most of the values are grouped around this line. The $\mathrm{IC}_{50}$-values of the two penicillins are closely correlated; very few points deviate more than two-fold from the line which represents the ten-fold difference. Yet the relation between the concentrations of methicillin and sodium penicillin $\mathrm{G}$ needed for in vitro inhibition is different in strains sensitive and those less sensitive to penicillin. Relatively more methicillin is needed in strains less sensitive to sodium penicillin G. It is evident that, apart from the fact that strains resistant to streptomycin are very rare among strains sensitive to sodium penicillin $G$ and methicillin, no further
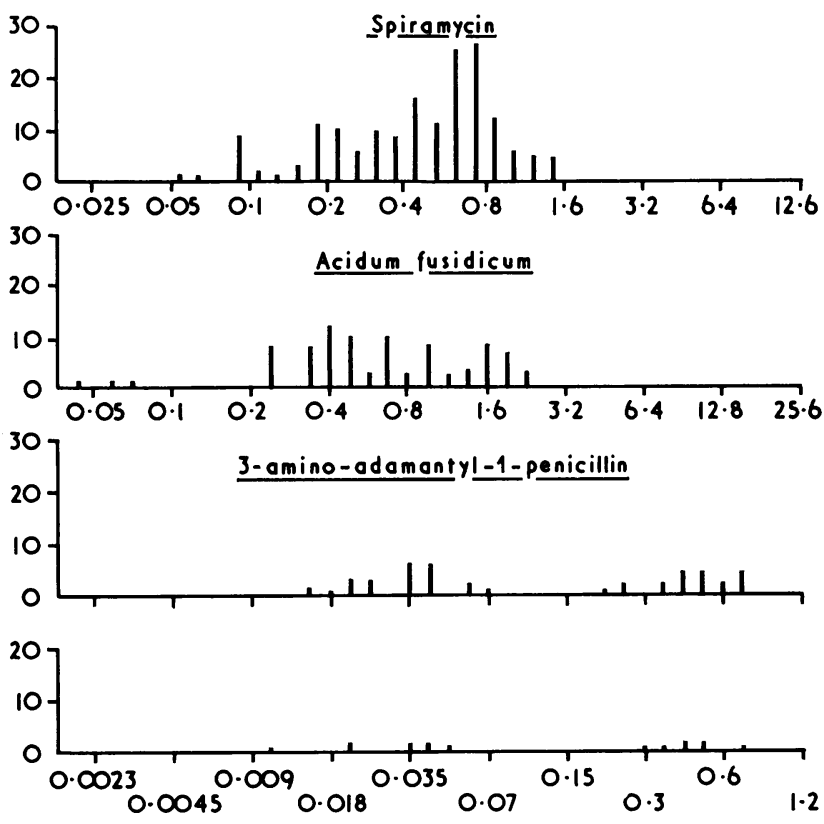

ICsO $\mu \mathrm{g} . / \mathrm{mI}$.

FIG. 2.- $\mathrm{IC}_{50}$-values in $\mu \mathrm{g} . / \mathrm{ml}$. of spiramycin, fusidic acid, and 3-amino-adamantyl-1-penicillin. Range and distribution.

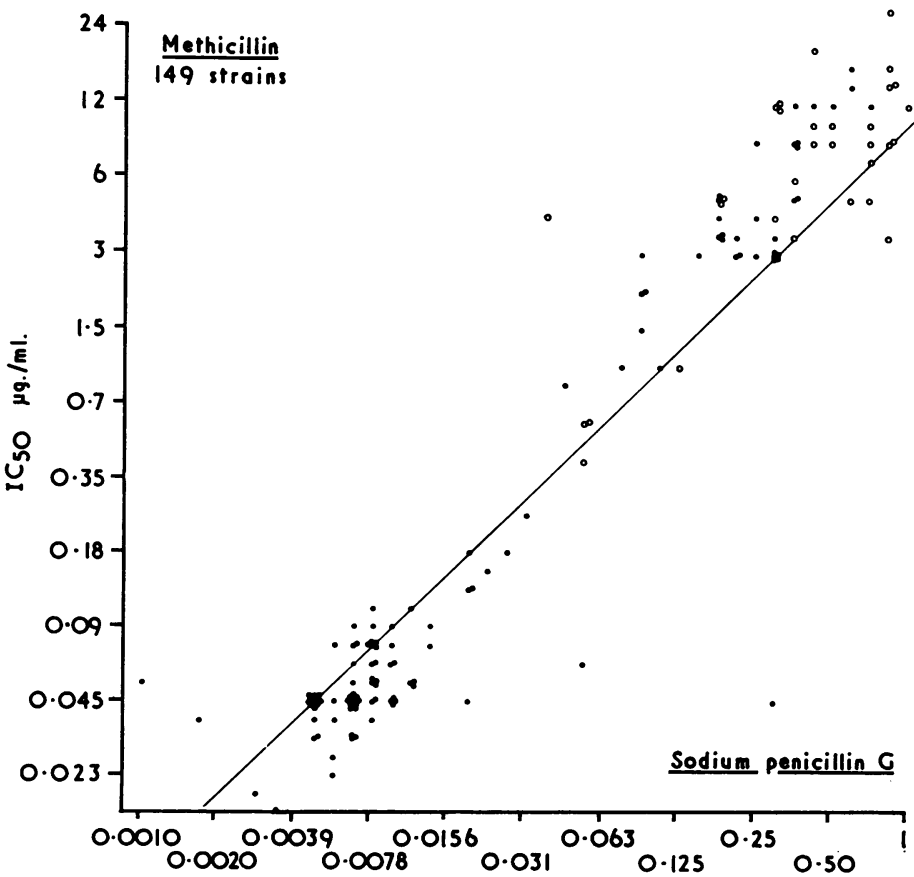

IC $50 \mu \mathrm{g} . / \mathrm{mI}$.

FIG. 3.-Comparison between sodium penicillin $G$ and methicillin. $\mathrm{IC}_{50}$-values in $\mu \mathrm{g} . / \mathrm{ml}$. 
grouping is obtained by distinction between strains resistant and sensitive to streptomycin.

Comparison with Oxacillin In Fig. 4 the $\mathrm{IC}_{50}$-values obtained with oxacillin in 88 strains are plotted on the ordinate. A straight line is drawn through $\mathrm{IC}_{50}$-values twenty-fold higher on the ordinate than those on the abscissa. Again the values are grouped around the line. In this case, however, the scattering of the points is wider than that seen in Fig. 3. Eight strains have $\mathrm{IC}_{50}$-values at about the limit between strains sensitive to sodium peniciilin $G$ and those less sensitive to this substance; four of them are comparatively sensitive to oxacillin and at the same time resistant to streptomycin.

Comparison with Ampicillin Altogether 180 strains were tested. Fig. 5 shows that, with few exceptions, the $\mathrm{IC}_{50}$-values of the strains sensitive to sodium penicillin $G$ form a cluster of points parallel to and above the line of identity, the ampicillin values being about two-fold higher than those of sodium penicillin $\mathrm{G}$.

However, at the limit between strains sensitive to and those less sensitive to sodium penicillin $G$, the points take a horizontal course which intersects the line of identity at an $\mathrm{IC}_{50}$-value of about $0 \cdot 125$ $\mu \mathrm{g} . / \mathrm{ml}$. At higher $\mathrm{IC}_{50}$-values the points tend to cluster parallel to the line and a little below; in this area most of the strains are resistant to streptomycin.

Comparison with 3-Amino-adamantyl-1-penicillin The comparison was made in 65 strains; Fig. 6 (overleaf) shows the results as in the preceding figures. The line of identity having been drawn, the pattern formed by the corresponding $\mathrm{IC}_{50}$-values resembles that seen in Fig. 5; a cluster of points parallel to and above the line is formed by the strains sensitive to sodium penicillin $G$. At the limit between the strains sensitive to and less sensitive to sodium penicillin $\mathrm{G}$, the cluster of points takes a horizontal course which intersects the line of identity at about $0.5 \mu \mathrm{g} . / \mathrm{ml}$. One strain which is resistant to streptomycin is comparatively more sensitive to 3-aminoadamantyl-1-penicillin than to sodium penicillin $G$.

Comparison with Spiramycin The comparison was based on the examination of 173 strains all isolated in 1963. In Fig. 7 (overleaf) the $\mathrm{IC}_{50}$-values with spiramycin are plotted on the ordinate. Ignoring the difference between the symbols for strains sensitive and resistant to streptomycin, the $\mathrm{IC}_{50^{-}}$ values to sodium penicillin $G$ and spiramycin do not seem to be correlated. If, however, only the strains resistant to streptomycin are considered, a positive correlation is seen between the penicillin $G$ values

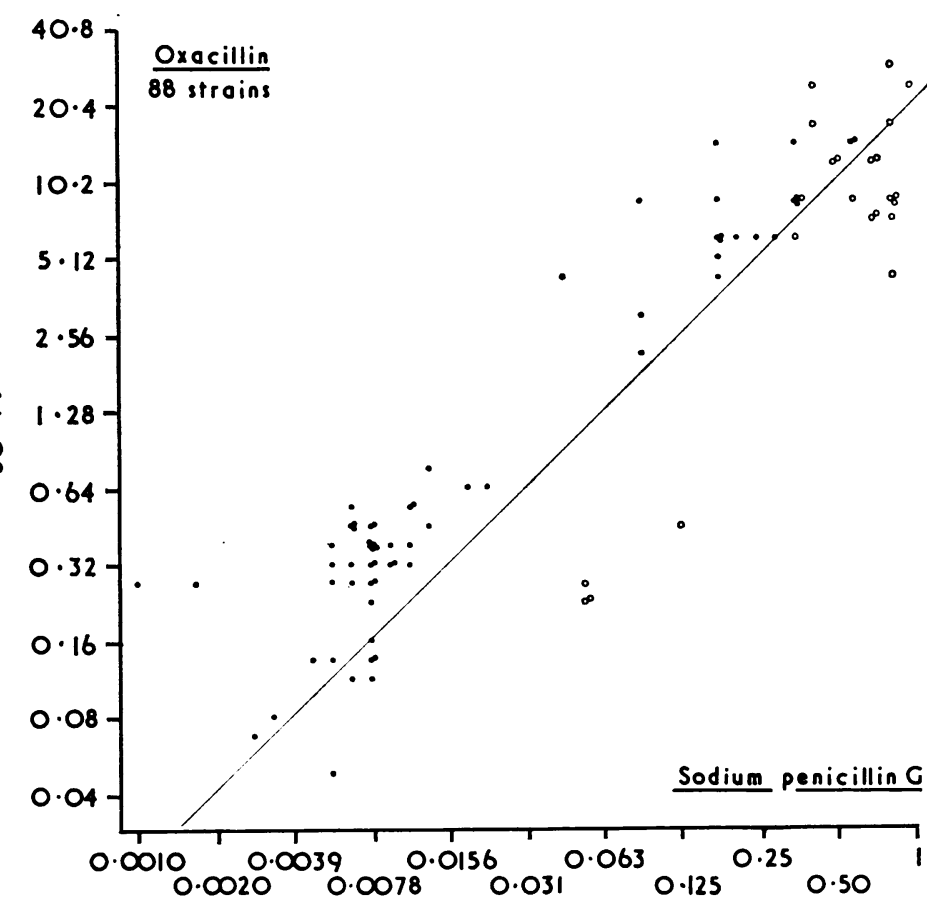

IC $_{50} \mu \mathrm{g} . / \mathrm{ml}$.

Fig. 4.-Comparison between sodium penicillin $G$ and oxacillin.

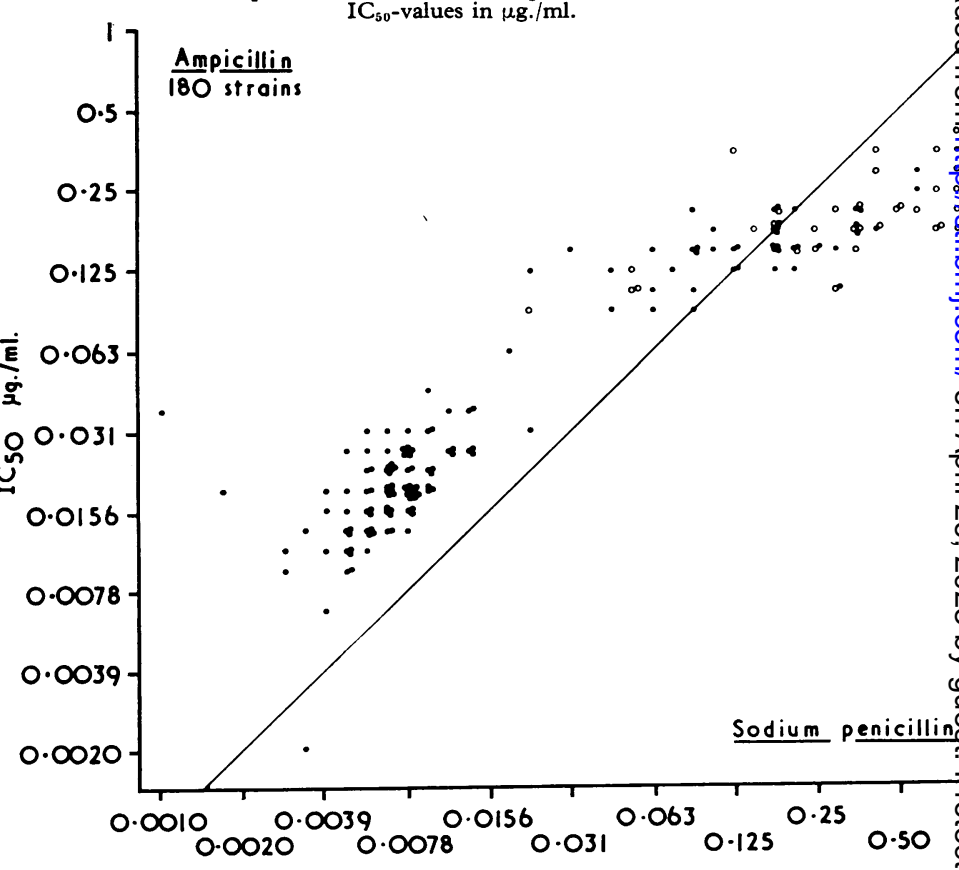

$I_{50} \mu \mathrm{g} . / \mathrm{mI}$.

FIG. 5.-Comparison between sodium penicillin $G$ and ampicillin. IC $_{50}$-values in $\mu \mathrm{g} . / \mathrm{ml}$. 


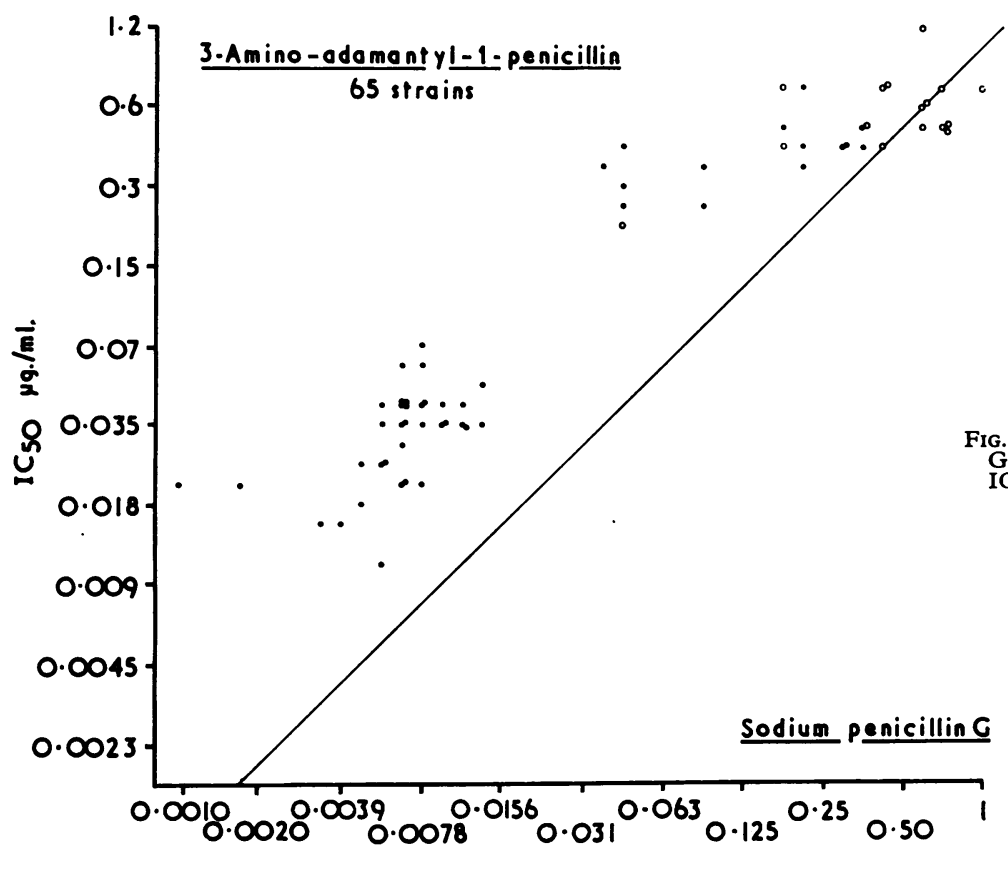

$I_{50} \mu 9 . / \mathrm{ml}$.

FIG. 7.-Comparison between sodium penicillin $G$ and spiramycin. $\mathrm{IC}_{50}$-values in $\mu \mathrm{g} . / \mathrm{ml}$.

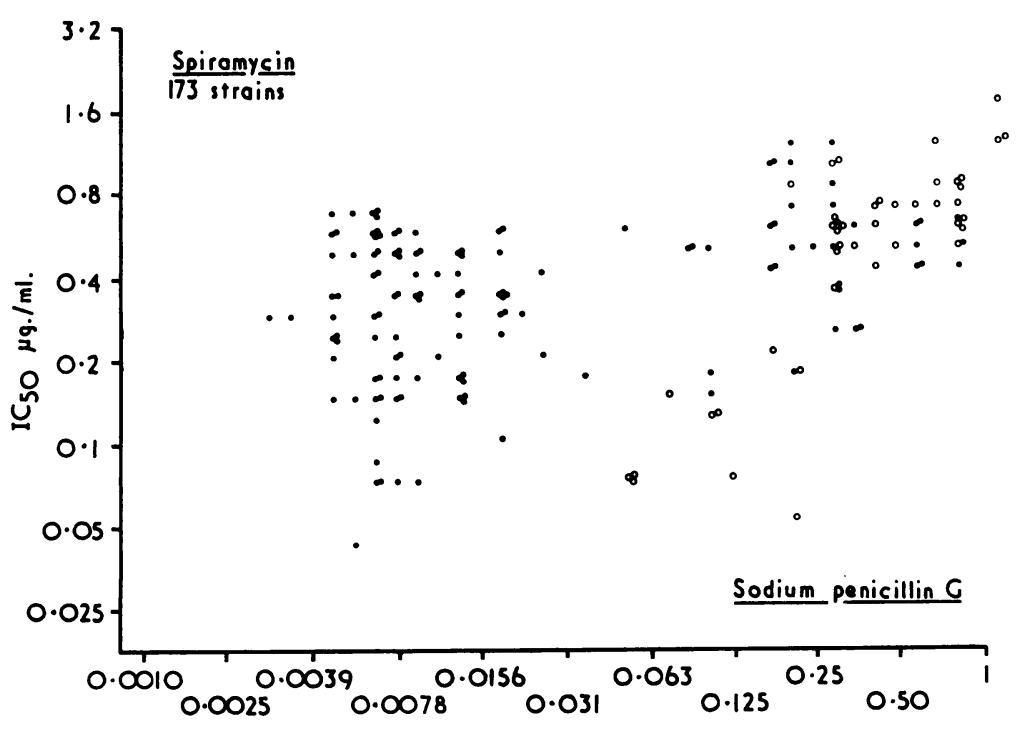

$1 C_{50} \mu 9 . / \mathrm{ml}$.

$\geqslant 0.063 \mu \mathrm{g} . / \mathrm{ml}$. and the corresponding spiramycin values. Fourteen strains have $\mathrm{IC}_{50}$-values close to the limit between high and low sensitivity to sodium penicillin $G$; seven of these strains are comparatively sensitive to spiramycin and at the same time resistant to streptomycin. Four of the latter were identical with four strains which were comparatively sensitive to oxacillin. 
Comparison with Fusidic Acid This comparison, which was based upon the observations of 96 strains isolated in 1962, is illustrated in Fig. 8; again the sodium penicillin $G$ values are plotted on the abscissa and the corresponding $\mathrm{IC}_{50}$-values of fusidic acid on the ordinate. No correlation is seen in strains sensitive to sodium penicillin G. If, however, the strains less sensitive to sodium penicillin $G$ are considered, a positive correlation is found between the $\mathrm{IC}_{50}$-values of sodium penicillin $\mathrm{G}$ (all $\geqq 0.63$ $\mu \mathrm{g} . / \mathrm{ml}$.) and fusidic acid. Eight strains show IC $_{50}$-values close to the limit between strains sensitive and less sensitive to sodium penicillin $G$; the strain most sensitive to fusidic acid is the only one which is resistant to streptomycin.

\section{Strains subcultured at Increasing Concentrations of Sodium Penicillin G}

Table II contains the average ratios between original $\mathrm{IC}_{50}$-values for seven different antibiotics and those of the two series of strains made artificially more resistant to sodium penicillin G. The five strains employed in these experiments were already less sensitive to sodium penicillin $\mathrm{G}$ and tetracycline; they were completely resistant to streptomycin. The relation to the two latter antibiotics remained unchanged, but to all five penicillins a significant increase in resistance was observed. The degree of the increase varies, being greater for methicillin, ampicillin, and 3-amino-adamantyl-1-penicillin than for oxacillin and sodium penicillin G. It is remarkable that minor but significant changes are also seen in the relation to spiramycin. In the most resistant series of strains, a slight increase in resistance is observed even in relation to fusidic acid.

TABLE II

MEAN RATIOS BETWEEN ORIGINAL AND ARTIFICIALLY INCREASED IC $_{50}$-VALUES OF FIVE GONOCOCCAL STRAINS BEFORE AND AFTER SUBCULTURING ON MEDIUM WITH SODIUM PENICILLIN G ADDED

\begin{tabular}{l|c|c}
\hline \multirow{2}{*}{\multicolumn{1}{c|}{ Antibiotic }} & \multicolumn{2}{|c}{ Ratios of IC $_{\text {s0 }}$-values* } \\
\cline { 2 - 3 } & $\begin{array}{c}\text { Pen. Res. I/ } \\
\text { Pen. Res. Orig. }\end{array}$ & $\begin{array}{c}\text { Pen. Res. II/ } \\
\text { Pen. Orig. }\end{array}$ \\
\hline 3-amino-adamantyl- & $2 \cdot 9$ & $10 \cdot 9$ \\
1-penicillin & $5 \cdot 1$ & $9 \cdot 7$ \\
Methicillin & $4 \cdot 5$ & $8 \cdot 0$ \\
Ampicillin & $3 \cdot 4$ & $5 \cdot 7$ \\
Oxacillin & $3 \cdot 4$ & $6 \cdot 7$ \\
\hline Sodium penicillin G & $2 \cdot 0$ & $2 \cdot 2$ \\
\hline Spiramycin & $1 \cdot 2$ & $1 \cdot 3$ \\
Fusidic acid & & \\
\hline
\end{tabular}

Pen. Res. Orig.: Mean of original $I_{60}$-values for five strains.

Pen. Res. I: Mean of $\mathrm{IC}_{50}$-values for the same five strains after 2 months' subculturing on medium with sodium penicillin $G$ added.

Pen. Res. II: Mean of $I_{50}$-values for the same five strains after 3 months' subculturing on medium with sodium penicillin $G$ added.

* The 95 per cent. limits of error are from 73 to 137 per cent. of tne ratios.

\section{Discussion}

Although the range and level of the $\mathrm{IC}_{50}$-values of the individual strains differed from one of the semisynthetic penicillins to the other, these values were closely correlated with those obtained with sodium penicillin $\mathrm{G}$, and thus they were all intercorrelated.

The level of the $\mathrm{IC}_{50}$-values varied with the

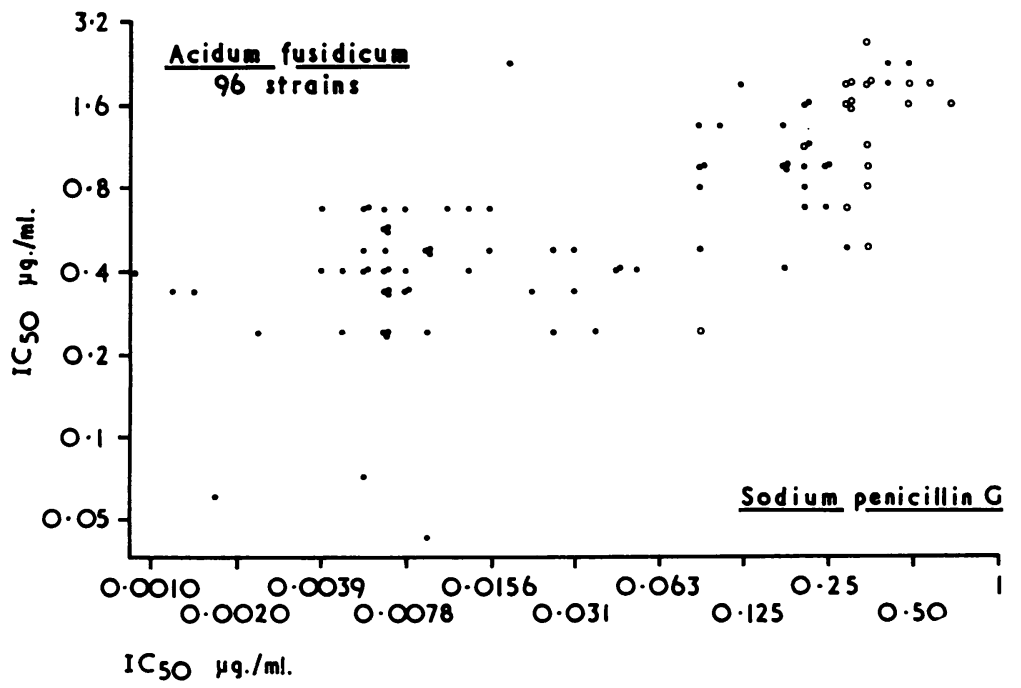

FIG. 8.-Comparison between sodium penicillin $G$ and fusidic acid. $\mathrm{IC}_{60}$-values in $\mu \mathrm{g} . / \mathrm{ml}$. 
molecular structure of the different penicillins, more specifically with the substitutions in their sidechains. In experiments with staphylococci, Gourevitch, Hunt, and Lein (1960) demonstrated that increasing side-chain length resulted in decreased activity. They found an overall correlation between the molecular weight of the side-chains and the amount of serum-binding, which increased with increasing length of these. In experimental infections of mice, the minimum inhibitory concentrations in 50 per cent. human serum were also positively correlated with the median curative doses.

Ampicillin The side-chain of ampicillin (D(-)1-aminobenzylpenicillin) is slightly different from that of sodium penicillin $G$ (sodium benzylpenicillin), the molecular weights of the two substances being nearly the same. Their $\mathrm{IC}_{50}$-values ranged from 0.002 to $0.5 \mu \mathrm{g} . / \mathrm{ml}$. (ampicillin) and from $\leqq 0.001$ to $1.41 \mu \mathrm{g}$. $/ \mathrm{ml}$. (sodium penicillin $\mathrm{G}$ ). The $\mathrm{IC}_{50}$-values of the more sensitive, naturallyoccurring strains were about twice as high with ampicillin than with sodium penicillin $G$, whereas an opposite tendency was observed in the less sensitive strains (Fig. 5). This is in agreement with findings reported by Ødegaard (1962a, b), who considered ampicillin to be the most effective of the oral penicillins tested in vitro, "and thus having valuable possibilities in the treatment of gonorrhoea". In a study on 130 gonococcal cultures, Alergant (1963) was unable to confirm these findings. However, in Alergant's material, the proportion of strains with highly-reduced sensitivity to penicillin was less than in that of Ødegaard (1962b). The $I C_{50}$-values of strains originally less sensitive to sodium penicillin $G$ in vitro were also lower to ampicillin than to sodium penicillin $G$, but they increased just as much to ampicillin as to sodium penicillin $G$ (Table II) in strains made artificially more resistant to sodium penicillin $\mathrm{G}$.

In clinical trials and compared on unit weight basis, it may hardly be possible to demonstrate any difference in effect between sodium penicillin $G$ and ampicillin. Some therapeutic reports deal with limited numbers of patients, and of those dealing with larger series (Bond, 1964; Marmell, Sills, Brown, and Prigot, 1964; Willcox, 1964a, b; Heinemann and Vinikoff, 1965) only a few contain information on the sensitivity in vitro of the strains involved. None of the papers combines contemporary comparison between ampicillin and sodium penicillin $G$ used in comparable amounts in a suitable number of patients, all the gonococcal strains from whom have been examined for sensitivity in vitro to the two antibiotics. At present it may be concluded that injections of procaine penicillin $G$ and ampicillin given orally are equally effective in the treatment of gonorrhoea when used in comparable amounts.

Methicillin and Oxacillin These have low affinities to penicillinases (beta-lactamases: Pollock, 1962); they have comparatively complex and heavy side-chains: 2,6-dimethoxyphenyl and 5-methyl-3phenyl-4-isoxazolyl, that of oxacillin being the heavier. Their $\mathrm{IC}_{50}$-values were ten-fold and twenty-fold higher than those of sodium penicillin G. Similar values were reported by Thayer and Axnick (1964). Methicillin ranged from 0.016 to $29 \mu \mathrm{g} . / \mathrm{ml}$. and oxacillin from 0.05 to $50 \mu \mathrm{g} . / \mathrm{ml}$. As would be expected, the strains made artificially more resistant to sodium penicillin $\mathrm{G}$ also became more resistant to methicillin and oxacillin. Of course, the two latter penicillins should not be used in the treatment of gonorrhoea; they are meant for the treatment of infections with penicillinase-producing micro-organisms, as for example penicillin-resistant staphylococci. The increased resistance of gonococci to sodium penicillin $G$ is due neither to betalactamase nor to acylase (amidase: English, McBride, and Huang, 1960), the mechanism of resistance being as yet unknown. It may be due to some properties that are unrelated to enzymatic activity.

Gonococci less sensitive to penicillin seem to differ from sensitive strains not only in their relation to penicillin; thus, the three chemically-different antibiotics (ristocetin, spiramycin, and fusidic acid) were differently effective in the two groups of strains. The relation to spiramycin and fusidic acid, neither of which has been used to any significant degree in the therapy of gonorrhoea, will be described below. Ristocetin, in low concentration, is at present incorporated in the medium used for primary isolation of gonococci (Thayer and Martin, 1964)*. A certain proportion of the gonococcal strains in circulation are inhibited completely by this concentration at which the growth of most Gram-positive micro-organisms is also completely inhibited. Strains less sensitive to penicillin are nearly always comparatively resistant to ristocetin, whereas those sensitive to penicillin show varying degrees of sensitivity to ristocetin (Reyn, unpublished data, 1965).

\footnotetext{
* Ristocetin (Spontin ${ }^{\circledR}$ Abbott) was removed from the market in 1964; it can be replaced by vancomycin (Vancocin (\$) Lilly) (Thayer and Martin, 1966). Ristocetin and vancomycin interfere in the synthesis of acetylmuramic acid, which, together with acetylglucosamine form the "backbone" of the cell wall in Staphylococcus aureus. At a later stage of the cell-wall formation, the closure of the polyglycin bridges, which normally bind together the two alternating glycopeptides, is inhibited by sodium penicillin $G$ (terminal cross-linking) (Strominger and Tipper, 1965).
} 
The resistance of staphylococci to penicillins (methicillin and cloxacillin) is not always due to enzymatic effects only (Eriksen and Erichsen, 1964; Farkas-Himsley and Soeprihatin, 1964). Another example is that of penicillinase-producing Klebsiella strains; it was found by Hamilton-Miller (1965) that in only two of twelve such strains was the penicillinase production primarily responsible for resistance to benzylpenicillin; nor was the permeability barrier of the other ten strains responsible. It was presumed that such resistance reflects "an innate lack of sensitivity of the cell-wall synthetizing complex to inhibition by penicillins".

\section{3-Amino-adamantyl-1-penicillin In spite of its} heavy side-chain, the last semi-synthetic penicillin, 3-amino-adamantyl-1-penicillin had $\mathrm{IC}_{50}$-values at the same level as that of sodium penicillin $G$ and ampicillin. The $\mathrm{IC}_{50}$-values ranged from 0.001 to $1 \mu \mathrm{g} . / \mathrm{ml}$. The relation between 3-amino-adamantyl1-penicillin and sodium penicillin $G$ for the individual strains resembled that between ampicillin and sodium penicillin $G$ (Figs 5 and 6). Both ampicillin and 3-amino-adamantyl-1-penicillin have a zwitterion which endows them with strongly hydrophilic properties (Abraham, 1965); apparently, in 3-amino-adamantyl-1-penicillin, this effect is strong enough to rule out completely the hydrophobic effect of the comparatively heavy side-chain. Possibly, the findings in vitro do reflect a genuine difference between sodium penicillin $G$ and the two "amino-penicillins" in the bactericidal effect on gonococci. Thus, ampicillin is known to be more active than sodium penicillin $G$ against Gramnegative bacteria such as Escherichia coli (Boman and Eriksson, 1963). However, different degrees in vitro and in vivo of binding to proteins (especially to albumin) may also be of significance. Generally, the portion bound to protein is considered as inactive against bacteria (Davis, 1943; Tompsett, Shultz and McDermott, 1947; Quinn, 1964). The percentage binding of the penicillins to serum proteins increases from ampicillin through sodium methicillin and penicillin G to oxacillin (Tompsett and others, 1947; Bond, 1964; Rolinson, 1964; Kunin, 1966); 3amino-adamantyl-1-penicillin is only slightly bound to serum proteins. The last has not been recommended for therapeutic use because it has been shown to be toxic in animal experiments (Tybring, personal communication, 1966).

Spiramycin The observation that a comparatively high degree of resistance to spiramycin was correlated with increased resistance to sodium penicillin $G$ is worthy of mention. In a previous investigation (Schmidt and others, 1965) dealing with the treatment of gonorrhoea with spiramycin, it was found that all the gonococcal strains from thirteen uncured patients were less sensitive to sodium penicillin $G$ in vitro. A correlation was also observed between the susceptibility to spiramycin and penicillin in vitro of 96 gonococcal strains.

Another peculiar feature observed in the present study was that, of the fourteen strains with moderately decreased sensitivity to sodium penicillin $G$, seven were highly sensitive to spiramycin but at the same time completely resistant to streptomycin. Four of these strains were also highly sensitive to oxacillin. Yet it is impossible to tell whether the "pecularity" lies in the high sensitivity of these strains to spiramycin (and oxacillin) or in the low sensitivity to spiramycin of the strains which were sensitive to streptomycin. Strains at this level of sensitivity to sodium penicillin $G$ are rare, and they may represent a group with special genetic qualities.

Of course, therapeutic habits will be reflected in the "antibiotic patterns" observed. For example, in France, where streptomycin has been used widely and penicillin to a much lesser degree, it was hardly possible to demonstrate any correlation between the inhibitory values of sodium penicillin $G$ and streptomycin (Durel, Roiron, and Delouche, 1961; Roiron, Rasetti-Nicod, and Durel, 1961), whereas in most other countries a strong positive correlation is the rule (e.g. Reyn and others, 1958; Reyn, 1963; Wilkinson, Race, and Curtis, 1967).

In Denmark, neither spiramycin nor fusidic acid has been much used in the treatment of gonorrhoea. The only known exceptions are the study of spiramycin by Schmidt and others (1965) and a short trial of fusidic acid at the Rudolph Bergh Hospital, Copenhagen, in 1962; the latter was abandoned because of frequent treatment failures and because it was not excreted in the urine (Perdrup, personal communication, 1966).

Fusidic Acid Cross-resistance between fusidic acid and various other antibiotics including sodium penicillin $G$ has been described in other microorganisms (Wallmark, 1964), whereas other investigators (Martin, Chabbert, Martin, and Berrod, 1963) observed no natural or artificial cross-resistance in vitro between fusidic acid and the antibiotics in current use. In the present study a positive correlation was found between sodium penicillin $G$ and fusidic acid in strains originally less sensitive to sodium penicillin $\mathrm{G}$. A slight increase in resistance to fusidic acid was also observed in strains made still more resistant to sodium penicillin G. 
Kanamycin and Streptomycin In a recent report, the sensitivity in vitro to penicillin of gonococcal strains was found to be positively correlated both with that to kanamycin and with that to streptomycin (Wilkinson and others, 1967). The authors thought that "this similarity in pattern to two different antibiotics was presumably due to the uneven distribution of streptomycin resistance in strains of gonococci of varying susceptibility to penicillin". However, the relation between penicillin and kanamycin was not analysed after grouping the strains according to their sensitivity to streptomycin. In the present paper, it was found that the relation between sodium penicillin $G$ and the other penicillins (Figs 3 to 6 ) did not depend upon the sensitivity to streptomycin. In contrast, a positive correlation between sodium penicillin $G$ and spiramycin was found only in strains which were resistant to streptomycin. A similar, but very doubtful tendency was observed for sodium penicillin $G$ and fusidic acid.

Chloramphenicol Gjessing and Ødegaard (1967) reported that the sensitivity of gonococci to penicillin was positively correlated with that to chloramphenicol. Thus, two more antibiotics may be added to those which are differently effective in strains with varying sensitivity to penicillin.

The positive correlation between the sensitivities to tetracyclines, streptomycin, and penicillin previously observed (Reyn and others, 1958; Reyn, 1963) should also be remembered.

At present we cannot explain the observed positive correlations between sodium penicillin $G$, and streptomycin, tetracycline, spiramycin, fusidic acid, kanamycin, and chloramphenicol in their activity on gonococci in vitro. Yet, it is most natural to explain the positive correlation between sodium penicillin $G$ and streptomycin mainly as a result $\mathbf{c f}$ sequential selection as a consequence of treatment. This assumption is supported by the early report by Miller and Bohnhoff (1946), who stated that gonococci made artificially resistant to either penicillin or streptomycin were susceptible to the other drug in vitro. Likewise, Meyer-Rohn (1958) found that strains which were either sensitive or resistant to streptomycin were equally difficult to make more resistant to penicillin.

It is noteworthy that patients infected with gonococcal strains resistant to streptomycin seem to respond to treatment with penicillin differently from those infected with strains sensitive to streptomycin. Thus, Rantasalo, Salo, and Wallenius (1964) observed that patients infected with gonococci less sensitive to penicillin may be divided into two groups according to the sensitivity to streptomycin. The lower doses of procaine penicillin were less effective in patients with gonococci less sensitive to penicillin and also resistant to streptomycin than in those with gonococci less sensitive to penicillin but sensitive to streptomycin.

For the last 25 years sodium penicillin $\mathrm{G}$ has been the drug of choice in the treatment of gonorrhoea. Streptomycin has been much used for nearly as long in many countries and in France almost exclusively. The tetracyclines have been employed to a considerable degree all over the world. Chloramphenicol has also been much used, whereas at the time when the present material was collected, spiramycin had mainly been used in France and not in Denmark, except in a special study (Schmidt and others, 1965).

Possibly, the observed positive correlation between the degree of sensitivity to sodium penicillin $G$ and that of the other drugs may all have the same explanation as that given for streptomycin, i.e. sequential selection as a consequence of treatment habits. The comparatively high resistance to ristocetin and to fusidic acid (and spiramycin ?) of strains less sensitive to penicillin suggests that this is not the only explanation.

Experiments in which strains sensitive to the various antibiotics have their sensitivities varied artificially might give valuable information regarding the mechanism of the positive correlations observed.

From a more practical point of view it is emphasized that before new antibiotics are recommended in the treatment of gonorrhoea their effect in vitro should be examined on groups of gonococcal strains with different sensitivities not only to penicillin but also to streptomycin and other antibiotics currently used in the treatment of gonorrhoea.

This recommendation has been made several times in the past, but with little success; its importance has recently been emphasized by Morton and Higson (1966). In many previous clinical trials of new antibiotics too little attention has been paid to the strains involved.

\section{Summary}

The relationships between the sensitivity in vitro of gonococci to sodium penicillin G, four semisynthetic penicillins, spiramycin, and fusidic acid were examined, using altogether 493 gonococcal strains covering a wide range of sensitivity to penicillin. The sensitivity to streptomycin and tetracycline of these strains varied also. The $\mathrm{IC}_{50}{ }^{-}$ values of the five penicillins were closely related, but on weight basis sodium penicillin $\mathrm{G}$, ampicillin, and 3-amino-adamantyl-1-penicillin were between ten 
and twenty times more effective than methicillin and oxacillin.

The two "amino-penicillins" had a slightly stronger effect than sodium penicillin $G$ on strains less sensitive to this substance. This was also the case when the "amino-penicillins" were tested against strains made more resistant to sodium penicillin G. However, seen in relation to their original sensitivity, the $\mathrm{IC}_{50}$-values were just as much increased as those to sodium penicillin $G$.

The effects of spiramycin in vitro and to a lesser degree that of fusidic acid were positively correlated with that of penicillin both against strains originally less sensitive to sodium penicillin $G$ and against strains made more resistant to this penicillin.

Gonococcal strains less sensitive to penicillin seem to differ in several ways from those which are sensitive. Thus, three chemically-different antibiotics (spiramycin, ristocetin, and fusidic acid) were differently effective in the two groups of strains. A peculiar feature was observed among the rare strains with moderately decreased sensitivity to sodium penicillin $\mathrm{G}$ : relatively high sensitivity to spiramycin was often combined with complete resistance to streptomycin.

As a consequence of the results reported, the employment of gonococcal strains with varying "antibiotic patterns" is recommended for trials in vitro of new antibiotics intended for future clinical use. Ideally, contemporary comparisons should be performed in suitable numbers of patients, and the infecting strains should be examined in vitro.

Grateful acknowledgements are expressed to the manufacturers of the various antibiotics for kindly providing the antibiotics used in this study.

\section{REFERENCES}

Abraham, E. P. (1965). Amer. F. Med., 39, 692.

Alergant, C. D. (1963). Brit. F. vener. Dis., 39, 225.

Boman, H. G., and Eriksson, K. G. (1963). F. gen. Microbiol., 31, 339.

Bond, J. M. (1964). Postgrad. med. F., 40, Suppl., p. 17, Dec. 1964.

Davis, B. D. (1943). F. clin. Invest., 22, 753.

Durel, P., Roiron, V., and Delouche, L. (1961). Bull. Wld Hlth Org., 24, 343.

English, A. R., McBride, T. J., and Huang, H. T. (1960). Proc. Soc. exp. Biol. (N.Y.), 104, 547.

Eriksen, K. R., and Erichsen, J. (1964). Acta path. microbiol. scand., 62, 255.

Farkas-Himsley, H., and Soeprihatin, S. D. (1964). Nature (Lond.), 202, 514.

Gjessing, H. C., and Ødegaard, K. (1967). Brit. F. vener. Dis., 43, 133.

Gourevitch, A., Hunt, G. A., and Lein, J. (1960). Antibiot. and Chemother., 10, 121.

Hamilton-Miller, J. M. T. (1965). F. gen. Microbiol., 41, 175.
Heinemann, S., and Vinikoff, M. R. (1965). Med. Tms $(N . Y), 93,290$.

Kunin, C. M. (1966). Clin. Pharmacol. Ther., 7, 166.

Marmell, M., Sills, J. R., Brown, C. D., and Prigot, A. (1964). N.Y. St. F. Med., 64, 985.

Martin, R., Chabbert, Y.-A., Martin, L., and Berrod, J. (1963). Presse méd., 71, 51.

Meyer-Rohn, J. (1958). Hautarzt, 9, 81.

Miller, C. P., and Bohnhoff, M. (1946). F. Amer. med. Ass., 130, 485.

Morton, R. S., and Higson, D. W. (1966). Brit. F. vener. Dis., 42, 175.

Ødegaard, K. (1962a). Brit. med. F., 1, 645. (1962b). T. norsk. Loegeforen., 82, 55.

Perdrup, A. (1966). Personal communication.

Pollock, M. R. (1962). Ciba Foundation, Study Group No. 13; "Resistance of Bacteria to the Penicillins", Churchill, London, pp. 56-75.

Quinn, E. L. (1964). Postgrad. med.F., 40: Suppl., p. 23, Dec. 1964.

Rantasalo, J., Salo, P. O., and Wallenius, J. O. (1964). Brit. F. vener. Dis., 40, 273.

Reyn, A. (1961). Ibid., 37, 145.

- (1963). Acta derm.-venereol. (Stockh.), 43, 380. (1966). WHO/INT/VDT/66.214.

- (1967). Unpublished data.

and Bentzon, M. W. (1961). Bull. Wld Hlth Org., 24, 333.

-, Bentzon, M. W., and Ericsson, H. (1963). Acta path. microbiol scand., 57, 235.

- Korner, B., and Bentzon, M. W. (1958). Brit. F. vener. Dis., 34, 227.

Roiron, V., Rasetti-Nicod, G., and Durel, P. (1961). Ann. Inst. Pasteur, 100, 445.

Rolinson, G. N. (1964). Postgrad. Med. F., 40, Suppl., p. 20, Dec. 1964.

Schmidt, H., and Larsen, S. O. (1962). Acta derm.venereol. (Stockh.), 42, 294.

- Niordson, A.-M., Reyn, A., and Bentzon, M. W. (1965). Brit. F. vener. Dis., 41, 120.

Strominger, J. L., and Tipper, D. J. (1965). Amer. F. Med., 39, 708.

Thayer, J. D., and Axnick, N. W. (1964). In "Antimicrobial Agents and Chemotherapy-1963", p.427.Proc.3rd Interscience Conference, New York. and Martin, J. E. (1964). Publ. Hlth Rep. (Wash.), 79, 49.

- (1966). Ibid., 81, 559.

Tompsett, R., Shultz, S., and McDermott, W. (1947). f. Bact., 53, 581 .

Tybring (1966). Personal communication.

Wallmark, G. (1964). Meeting of Svenska Läkaresellskapets Sektion för Mikrobiologi, Stockholm, March, 1964.

Wilkinson, A. E., Race, J. W., and Curtis, F. R. (1967). Postgrad. med. F., 43, Suppl., p. 65, May, 1967.

Willcox, R. R. (1964a). Ibid., 40, Suppl., p. 202.

- (1964b). Acta derm.-venereol. (Stockh.), 44, 228.

La sensibilité du $N$. gonorrhoeae à la pénicilline $\mathbf{G}$ sodique, à quatre pénicillines semi-synthétiques, à la spiramycine et à l'acide fusidique

RÉsumé

La relation entre la sensibilité des gonocoques in vitro à la pénicilline $G$ sodique, à quatre pénicillines semi- 
synthétiques, à la spiramycine et à l'acide fusidique a été examinée en se servant de 493 souches de gonocoques couvrant ainsi une large série de gonocoques sensibles à la pénicilline. La sensibilité de ces souches à la streptomycine et à la tétracycline a aussi été variable. Les valeurs $\mathrm{IC}_{50}$ des cinq pénicillines avaient une relation étroite, mais par rapport au poids la pénicilline $\mathbf{G}$ sodique, l'ampicilline et la 3-amino-adamantyle-1-pénicilline étaient entre dix fois et vingt fois plus effectives que la méthicilline et l'oxacilline.

Les deux "amino-pénicillines" avaient un effet légèrement supérieur à la pénicilline $G$ sodique sur les souches montrant une sensibilité moindre au dernier medicament. Cela a aussi été le cas quand les "aminopénicillines" ont été testées avec les souches qui avaient été rendues plus résistantes à la pénicilline $\mathbf{G}$ sodique. Cependant considérant la relation à leur sensibilité première, les valeurs $\mathrm{IC}_{50}$ avaient augmenté dans la même proportion que celles obtenues avec la pénicilline $G$ sodique.

L'effet de la spiramycine in vitro et à un degré inférieur celui de l'acide fusidique ont été en corrélation positive à celui de la pénicilline sur les souches qui avaient été au debut moins sensibles à la pénicilline $G$ sodique et sur les souches rendues plus résistantes à cette même pénicilline.

Les souches de gonocoques moins sensibles à la pénicilline semblent être différentes de plusieurs façons à celles qui sont sensibles. Ainsi, les trois antibiotiques qui diffèrent chimiquement (la spiramycine, la ristocétine et l'acide fusidique) avaient un effet différent sur les deux groupes de souches. Un fait singulier a été observé parmi les souches rares montrant une sensibilité légèrement moindre à la pénicilline $G$ sodique, c'est à dire une sensibilité relativement élevée à la spiramycine et qui était souvent combinée à une résistance totale à la streptomycine.

Découlant des résultats rapportés, l'emploi des souches de gonocoques montrant des réactions diverses envers les antibiotiques est recommandé pour des essais in vitro des nouveaux antibiotiques qui pourraient être employés cliniquement dans l'avenir.

Idéalement des comparaisons devraient être faites en même temps chez un nombre approprié de sujets, et les souches devraient être examinées in vitro. 